\title{
Addressing alcohol use in community sports clubs: attitudes of club representatives
}

\author{
Luke Wolfenden \\ The University of Newcastle, New South Wales; NSW Cancer Institute \\ Melanie Kingsland \\ The University of Newcastle, New South Wales; Hunter New England \\ Population Health, New South Wales

\section{Bosco Rowland} \\ Deakin University, Victoria \\ Vanessa Kennedy \\ Australian Drug Foundation, Victoria \\ Karen Gillham \\ Hunter New England Population Health, New South Wales \\ John Wiggers \\ The University of Newcastle, New South Wales; Hunter New England \\ Population Health, New South Wales
}

Alcohol has been characterised as among the most harmful drugs on the planet. ${ }^{1}$ Excessive alcohol consumption has been found to be particularly prevalent among sports participants. ${ }^{2,3}$ The promotion of alcohol at sporting events and venues, sponsorship by the alcohol industry of individual athletes and sports clubs, and the engagement of clubs and players in practices such as drinking games and alcohol awards have been associated with increased levels of alcohol consumption. ${ }^{4,5}$ Sporting club based interventions which attempt to address these and other practices associated with excessive consumption therefore may represent an effective strategy in reducing harm among sporting club members.

Despite the merits of intervention, a recent systematic review failed to identify interventions (evaluated using experimental or quasiexperimental designs) targeting excessive alcohol use in this setting. ${ }^{6}$ In order to assess how amenable sports club representatives may be to interventions targeting alcohol use we conducted a telephone survey of club representatives (presidents or nominated representatives) of community Australian Rules Football (or AFL), Rugby League, Rugby Union and Soccer (European football) clubs in New South Wales, Australia. Clubs in the Hunter, New England and selected Sydney metropolitan regions were sampled from a database compiled from sports associations, council listings and web searches. To be eligible for the study clubs were required to have senior teams (players $>18$ years of age), more than 40 members, to have legally sold or supplied alcohol and not be involved in an existing program to reduce alcoholrelated harm. Club representatives were mailed a study information statement and consent form and the representatives of consenting clubs completed a structured computer assisted telephone interview conducted by a trained research assistant between May and September 
2009. As part of the survey, club representatives were asked to respond using a four point Likert scale (strongly agree, agree, disagree, strongly disagree) to a series of statements about alcohol use and alcohol related practices at their club.

In total 101 (44\% of eligible clubs approached) provided consent and completed the telephone interview. There were no significant differences between participating clubs and clubs which did not participate in the study in terms of geographic locality or football code. A third of clubs were from Rugby League, $29 \%$ from Rugby Union, 25\% from Soccer and 14\% from AFL codes; $55 \%$ were clubs with greater than 150 members; and $80 \%$ were clubs from Major City regions. ${ }^{7}$ Club representative responses to the survey items are reported in Table 1.

Most clubs representatives agreed (95-99\%) that clubs are an important setting to promote healthy lifestyles, that it is important that clubs ensure alcohol is served responsibly, and that doing so is a responsibility of the club. Nonetheless, most clubs believed that players often consume too much alcohol (55\%), and that their club could benefit from assistance to encourage responsible alcohol consumption $(75 \%)$. Such findings suggest that clubs may be positively predisposed to supportive interventions to address alcohol use among club members through improving club practices regarding alcohol provision.

Supporting clubs to modify alcohol related practices, however, is likely to represent a considerable challenge given the perceived dependence of clubs on the sale of alcohol and alcohol related sponsorship (Table 1). Importantly, however, early evidence from interventions with community sports clubs suggest that reducing

\begin{tabular}{|c|c|c|}
\hline & $n$ & $\begin{array}{l}\text { Strongly } \\
\text { agree / } \\
\text { agree (\%) }\end{array}$ \\
\hline $\begin{array}{l}\text { Sporting clubs play an important role in } \\
\text { promoting healthy lifestyles to their club } \\
\text { members }\end{array}$ & 96 & $95 \%$ \\
\hline $\begin{array}{l}\text { Providing a healthy and safe environment will } \\
\text { encourage members to join our club }\end{array}$ & 96 & $95 \%$ \\
\hline $\begin{array}{l}\text { Club players and members often consume too } \\
\text { much alcohol }\end{array}$ & 56 & $55 \%$ \\
\hline $\begin{array}{l}\text { It is important for sporting clubs to ensure that } \\
\text { alcohol is served responsibly }\end{array}$ & 100 & $99 \%$ \\
\hline $\begin{array}{l}\text { Our club could benefit from assistance to } \\
\text { encourage responsible alcohol consumption at } \\
\text { club venues }\end{array}$ & 76 & $75 \%$ \\
\hline $\begin{array}{l}\text { Our club is responsible for ensuring players and } \\
\text { spectators do not consume too much alcohol at } \\
\text { club venues and events }\end{array}$ & 100 & $99 \%$ \\
\hline $\begin{array}{l}\text { Players would not want to be part of a club that } \\
\text { had strict rules around alcohol consumption } \\
\text { at club venues and club event (e.g. banning } \\
\text { drinking games) }\end{array}$ & 15 & $15 \%$ \\
\hline $\begin{array}{l}\text { It would be difficult for our club to survive } \\
\text { without revenue from the sale of alcohol }\end{array}$ & 51 & $51 \%$ \\
\hline $\begin{array}{l}\text { It would be difficult for our club to survive } \\
\text { without revenue from sponsorship }\end{array}$ & 96 & $95 \%$ \\
\hline
\end{tabular}

excessive alcohol consumption at sporting club fixtures can be achieved without compromising club revenue, and may improve the viability of community sports clubs through increased membership. ${ }^{8,9}$ If these findings are substantiated as part of more rigorous trials, such interventions may address concerns of club management and represent attractive public health interventions to reduce alcohol misuse, and encourage greater community participation in sport.

\section{References}

1. World Health Organization. WHO Expert Committee on Problems Related to Alcohol Consumption. Geneva (CHE): WHO; 2007.

2. Martens MP, Dams-O'Connor K, Beck NC. A systematic review of college student-athlete drinking: Prevalence rates, sport-related factors, and interventions. J Subst Abuse Treat. 2006;31(3):305-16.

3. O'Brien KS, Blackie JM, Hunter JA. Hazardous drinking in elite New Zealand Sportspeople. Alcohol Alcohol. 2005;40(3):239-41.

4. Dietze PM, Fitzgerland JL, Jenkinson RA. Drinking by professional Australian Football League (AFL) players: prevalence and correlates of risk. Med J Aust. 2008;189(9):479-83.

5. O'Brien KS, Kypri K. Alcohol industry sponsorship and hazardous drinking among sportspeople. Addiction. 2008;103(12):1961-6.

6. Priest N, Armstrong R, Doyle J, Waters E. Policy interventions implemented through sporting organisations for promoting healthy behaviour change (Cochrane Review). In: The Cochrane Database of Systematic Reviews; Issue 3, 2008. Chichester (UK): John Wiley; 2008.

7. Australian Bureau of Statistics. 1216.0 - Statistical Geography Volume 1 Australian Standard Geographical Classification (ASGC), Jul 2006. [cited 2011 Jun]. Available from: http://www.abs.gov.au/AUSSTATS/abs@.nsf/ Lookup/1216.0Main+Features1Jul\%202006?OpenDocument

8. Duff C, Munro G. Preventing alcohol-related problems in community sports clubs: the Good Sports program. Subst Use Misuse. 2007;42:12-13.

9. Munro G. Challenging the culture of sport and alcohol. Int J Drug Policy. 2001;11:199-202.

Correspondence to: Dr Luke Wolfenden, Hunter New England Population Health, Locked Bag No. 10, Wallsend, NSW 2287; e-mail: luke.wolfenden@ hnehealth.nsw.gov.au 